\title{
INTERFUNCTIONAL COORDINATION FROM COMPANY FUNCTIONS POINT OF VIEW
}

\author{
Vladimír Bartošek ${ }^{1}$, Eva Tomášková ${ }^{2}$ \\ ${ }^{1}$ Brno University of Technology, Faculty of Business and Management, Kolejni 2906/4, 61200 Brno \\ Email:bartosek@fbm.vutbr.cz. \\ ${ }^{2}$ Masaryk University, The Faculty of Law, Veveři 70, 61180 Brno \\ Email:eva.tomaskova@law.muni.cz
}

\begin{abstract}
The primary aim of this paper is to investigate the evolution of interfunctional coordination theory from the marketing and logistics point of view. The paper also discusses the key attributes of interfunctional coordination from the above mentioned perspectives in present network business environment. Special added value of the paper is in examining the interfunctional coordination via exploratory research from quantitative and qualitative points of view. The principles of external business environment complexity and internal collaboration built up new barriers of interfunctional coordination implementation. The paper identified source and parts of internal and external barriers of interfunctional coordination implementation. Finally is formulated recommendation how to understand external surroundings in relation to internal requirements of interfunctional coordination. At the end of the article is presented solution how to eliminate barriers of interfunctional coordination via application one of the methodologies of enterprise engineering and integration.
\end{abstract}

Keywords: collaboration, interfunctional coordination, marketing, supply chain management.

JEL classification: M11, M31

Doručeno redakci: 25.6.2012; Recenzováno: 26.2.2013; 6.3.2013; Schváleno k publikování: 19.6.2013

\section{Introduction}

Present dynamic and turbulence development of entrepreneurial surroundings constituted new corporate business structure, which is based on varied type of virtual or physical configuration of networks (e. g. supply chains, networks, clusters etc.). In this environment it is difficult to manage each enterprise or company's function separately. Many companies in this fastchanging environment need to restructure and rebuild up their management an organization approaches to meet new competitive conditions. One of the main tools, which help enterprises to survive and achieve competitive advantage, is interfunctional coordination. First mention of interfunctional coordination is known in the early of seventies $20^{\text {th }}$ century. Interfunctional coordination is mentioned in different approaches as management, marketing, logistics or information technology science, but interfunctional coordination is became the most popular during the last years. Present topics of interest among managers and researchers are how to find out optimal level of interfunctional coordination as well as how to manage them in present business conditions. Moreover are known some issues connected with interfunctional coordination: how to determine interfunctional coordination; how to find out which factors influence interfunctional coordination and how could be implement interfunctional coordination. The following article diversifies and analyzes interfunctional coordination and examines logistics and marketing background of interfunctional coordination in present complex entrepreneurship environment. 


\section{Interfunctional Coordination}

Multidisciplinary research activities in interfunctional coordination (IFC) are known by the end of the nineties. According to the own author's historical literature categorization survey, which is shown in Table 1, it is obvious that IFC was concerned with different meaning. As well as IFC was studied in different enterprises: small (O'Dwyer and Ledwith (2009) or Deng and Dart (1999)) and medium sized enterprises and large corporates (Jaworski and Kohli (1993) or Tomášková (2005)). Nevertheless, the term "inter-functional coordination" has been known for more than forty years. One of the first definitions of IFC was created by Shapiro. Shapiro (1987) has dealt with cross-functional coordination (CFC). CFC causes internal functional boundaries to lose meaning. Shapiro determined 6 approaches to achieve CFC components:

1. Unific holistic strategy;

2. Organization structure or management hierarchy;

3. Process management and systems;

4. Information systems (IS) and information systems management (ISM);

5. Informal social systems and culture;

6. Employees selection and promotion.

The result of Shapiro's IFC meaning, was harmonization of all internal functions and processes in a company. It consists of two parts, namely corporate culture and information coordination. IFC refers to the degree of co-operation between the different departments within the organization. (Tay and Tay, 2007) In the turn of the center is IFC perceived as communication.

Table 1: A Categorisation of Literature on Interfunctional Coordination

\begin{tabular}{|c|c|c|}
\hline Author(s) & $\begin{array}{c}\text { Interfunctional } \\
\text { Coordination Topics }\end{array}$ & $\begin{array}{l}\text { Examples of Main } \\
\text { JEL Group Classification }\end{array}$ \\
\hline Kohli and Jaworski (1990) & Marketing & Marketing and advertising theory (M 3) \\
\hline Rafiq and Ahmed (1993) & $\begin{array}{l}\text { Human } \\
\text { Management }\end{array}$ & Economic Development (M 11, O 15) \\
\hline McNaughton et al. (1999) & $\begin{array}{l}\text { Intranet and Groupware } \\
\text { Technology }\end{array}$ & Business Administration (M 15) \\
\hline Mentzer (2001) & Supply Chain Management & Production and Organization (D 21) \\
\hline Schiebel and Pochtrager (2003) & Social Sciences & $\begin{array}{l}\text { Firm Objectives, Organization and } \\
\text { Behaviour (L 21) }\end{array}$ \\
\hline $\begin{array}{l}\text { Simatupang, Sandroto and Lubis } \\
\text { (2004) }\end{array}$ & Supply Chain Management & Production and Organization (D 21) \\
\hline Danese and Romano (2004) & $\begin{array}{l}\text { Planning of } \\
\text { Management }\end{array}$ & Business Administration (M 11) \\
\hline Auh and Menguc (2005) & $\begin{array}{l}\text { Top Management Team } \\
\text { Diversity }\end{array}$ & Production and Organizations (D 23) \\
\hline Pirithiviraj and Kajendra (2010) & $\begin{array}{l}\text { Corporate } \\
\text { Responsibility }\end{array}$ & $\begin{array}{l}\text { Corporate Culture, Social Responsibility } \\
\text { (M 14) }\end{array}$ \\
\hline
\end{tabular}

Zahra and George (2002) pointed out that IFC integrates formal and informal social adaptation mechanisms of enterprise. Basic antecedents and consequences of IFC are illustrated in Figure 1 by Mentzer's model. The author's approach to IFC model constitution is based on marketing conceptualization of market orientation as a nature of IFC, which has general philosophical antecedents and consequences on business management and inter-firm relationships. 
In the early $21^{\text {st }}$ century the IFC definition was extended to the present form. There are two main attitudes toward IFC:

I. as only sharing information, cooperation of departments and coordination of organization activities, e.g. Tay and Tay (2007).

II. involves not only sharing information and coordination of activities, however, sharing resources for preparing coordinated activities is required, e. g. Bouranta et al. (2005); Peng and George (2011).

Figure 1: An Integrated Model of Interfunctional Coordination

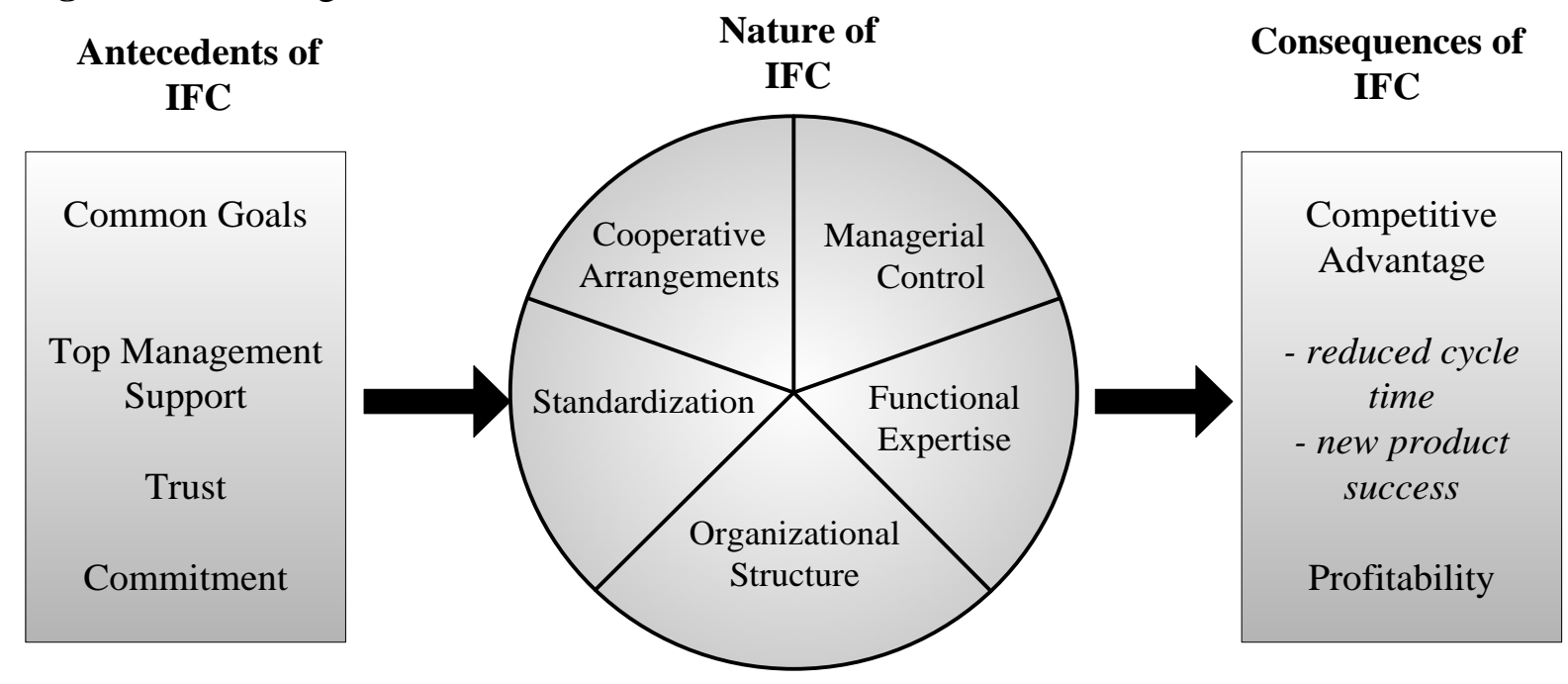

Source: Mentzer (2001)

\section{Research Questions}

Although IFC is related to many disciplines as it is confirmed by results in Table 1, this article will focus on IFC research from marketing theory point of view, which will be connected to logistics understanding and explanation of IFC issues. We would like to find out the principles and connections at the both sides of above mentioned scientific disciplines. The fundamental step for exploratory research of IFC was formulation of several main research questions (RQ). The first and the second questions are focused on IFC from interdisciplinary, integration and general points of view. RQ1 and 2 are trying to find out a link between IFC from the marketing and logistics management area. In addition, there was formulated the third question (RQ3), which is concentrated on external interaction, its realization and connected problems.

RQ1: Does any connection between interfunctional coordination, marketing and logistics management concept in present business environment exist?

RQ2: How could be described the relation between IFC from marketing and logistics theory?

RQ3: What kind of barriers and problems are connected with collaboration via IFC in marketing/logistics implementation?

\section{Methodology and Research Methods Description}

In this article exploratory research is used. Exploratory research is the combination of secondary data analysis with the pilot case studies analysis, and experience surveys analysis (Collis and Hussey, 2003), which corresponds with RQ and the proposed design. The analytical process of this paper consists of the inductive research approach, which is based on different IFC taxonomy understanding, the review of business processes from the main 
company functions point of view. Additionally, case study research was based on attributes searching how to understand IFC patterns within specific elements of present network environment. In this exploratory research there is also defined research limitation, which must be considered:

- The proposed research model does not consider longitudinal primary data analysis.

- The research model could not contain complete multi-language research without other foreign languages determination.

\section{Interfunctional Coordination in Marketing}

Marketing is not interpreted as a separate management function. Mentzer (2001) proposed that a firm should consider managing a set of fundamental business processes, rather than independent functional departments.

The first information about IFC from marketing point of view was presented by Lawrence and Lorch (1967). They defined IFC as an integration of the quality of sale and collaboration among departments with the goal to achieve unity of effort by the demands of the environment. Other significant definition offered Porter (1985). According to Porter, IFC contributes to creation of value for targeted customers and helps to offer a quick response to customers. Day and Klein (1987) guess that implementation of IFC is especially through tight controls or cooperative arrangements. The advantage of this sense of IFC is that workers may control if they contribute to fulfil goals. Kahn and Mentzer (1998) agree with this conception. Furthermore, coordination should be predicated on interaction and allow contact of marketing department with other departments through information flows.

IFC obtained new significance at early 90s. The first interesting definition of coordination was created by Shapiro (1987). His definition is mentioned above. Shapiro (1987) tried to determine whole necessary approaches for achieving the CFC definition. Narver and Slater (1990) reviewed the term market orientation and IFC got a new dimension. IFC becomes one of necessary principles of market orientation. It coordinates utilization of company resources in creating improved value for target customers in the whole purchase process (Narver and Slater (1990), Song and Montoya-Weiss (2001)). Kohli and Jaworski (1990) added that market department is not only responsible for marketing. It is necessary to have a perfect coordination of all departments. Hodge et al. (1996) determine IFC as coordination among various tasks to ensure overall goals and specifically this type of IFC definitions are presented in a lot of studies dealing with market orientation.

Sinkula (2004) noticed that IFC helps an organization to become a learning organization. According to him, IFC presents a channel for communication between customers and an organization. It is established from market intelligence about customers, competitors, and external environment. According to Grinstein and Workman (2004) IFC shows the level of an organization's interaction and communication.

Woodside (2005) extended understanding of IFC about demonstrating willingness by employees to communicate, think and work together with the goal to achieve objectives, effectiveness, competitive advantage and finally higher business performance. Zhao and Cavusgil (2006) showed IFC as an integration of all functions in an organization to satisfy and serve customer needs, wishes, and demand.

Tay \& Tay (2007) perceived IFC as a quick alert of one department to another department when there is something new to the competitors. In this attitude it is obvious that IFC presents 
especially cooperation between the different functions or departments within the organization. Farzard et al. (2008) added to the IFC definition strategy and organization structure.

\section{Interfunctional Coordination in Logistics Management}

The first mention of IFC was related to the term interfirm cooperation in sense of supply chain management ${ }^{1}$ (SCM) at the beginning of 1970. The goal of IFC was to integrate major business processes to increase customer satisfaction and cost saving. (Min et al., 2004) Firstly Dwyer and Tanner (1999) furthermore Tay and Tay (2007) marked IFC as internal partnering among the departments as marketing, research and development (R\&D), purchasing, manufacturing and finance. In the same way Mentzer (2000) defined an integrated model of IFC as an integral part of logistics management ${ }^{2}$. The same author perceives IFC with interfirm cooperation as essential elements of SCM. What is more, Mentzer built up the whole SCM model on key business processes of IFC, which includes supply and marketing oriented functions. With regard to compared past literature review (e. g. Christopher (1998), Mentzer (2000)) with present logistics (e. g. Chopra (2009), Scott, et al. (2011)) and IFC concepts (e. g. Tay and Tay (2007)) it is clear, that logistics focuses more on the both sides of relationships with customers and also suppliers. On the one hand, over the past decade a number of different frameworks or classification schemes of relationships from whole SCM theory have been depicted (Min and Mentzer (2000), Hingley (2001), Christopher (2004) etc.), but on the other hand similar research in Customer Relationship Management and Supplier Relationship Management theory has been realised (CRM) (Ballou (2007), Heczková and Stoklasa (2011)) (SRM) (Jüttner et al. (2010), McCarthy-Byrne and Mentzer (2011)). Probably the most important findings were published by Horvath (2001), who specified IFC and SCM relation by findings that collaboration among all participants in the value chain, whatever their size, function or relative position is the main driving force of effective SCM. Similarly Sahay (2003) confirmed Horvath's findings by the conclusion that key components of SCM are collaboration between manufacturers, customers and logistics service providers (LSP) - the third, the fourth or X party logistics management. In the same way Chopra and Meindl (2009) gave opinion on coordination, which mentioned that "The most important SCM catalysts are information and communication technologies (ICT), coordination, and collaboration."

In the same SCM/IFC meaning Kahn and Mentzer (1996) defined collaboration as philosophy for interdepartmental relationships. In addition to Chopra and Meindl's (2009) and Cheng's, et al. (2010) words, Horvath (2001) extended collaboration theory about 8 key network attributes. One of the main important key network attributes are systems and channel integration. The author concludes that the most advanced infrastructures fail if a business does not restructure according to existing overall business processes that take full advantage of new capabilities and opportunities.

\footnotetext{
${ }^{1}$ Lambert, Cooper and Pagh (2001), Lummus, Krumwiede and Vokurka (2001) have discussed the differences between supply chain management (SCM) and logistics management. The term of SCM came into widespread use from 90s (e. i. Wal-Mart, Hewlett-Packard etc.) and also scientific interest by Lambert, Cooper and Pagh (2001), Christopher (2005) mostly in the context of logistics. The field of SCM has recently gained much attention from many perspectives. Business philosophy of SCM is defined as an integrative model of the marketing concept (marketing orientation, relationship marketing and supply management) and logistics activities.

${ }^{2}$ It is an integrating function which coordinates and optimises all logistics activities, as well as integrates logistics activities with other functions including marketing, manufacturing, finance and information technology. Farooqui (2010)
} 
With regard to SCM and IFC basis Cheng, et al. (2010) stressed IT/ICT key crucial role in integration and collaboration of SCM by findings that "Collaboration involves the highest level of intensity of relationship, within which the trading partners integrate their major consumer processes to achieve their common, desired goals based upon mutual trust and commitment." Hence it is possible to conclude and agree with Hingley, et al. (2011), who stressed that collaboration among partners underlies SCM development across enterprises relationship management, purchasing, customer service and cost control to reach total supply chain systems efficiency.

A number of academic disciplines and authors (Kahn and Mentzer (1996), Gimenez and Ventura (2005), Zailani et al. (2005), Gimenez (2006), Aryee et al. (2008), Berente, Vandenbosch and Aubert (2009), Costes et al. (2009)) are addressed the attention on both side of external and internal logistics integration. Costes et al. (2009) mentioned the main streams of literature which focus on different levels in integration:

- Organizational or interdepartmental integration (Kahn and Mentzer, 1996);

- Information - technical integration;

- Process integration.

Gimenez (2006) has considered integration of logistics with other company functional areas, mainly marketing and production. The integration model of logistics-marketing and logisticsproduction internal integration was fully confirmed by author's research as a tool, which increases competitiveness of a company. But how could be those different functions such SCM and marketing managed? The answer was identified by Shapiro (1987), Kahn and Mentzer (1996) and newly Costes et al. (2009), who mentioned importance and solution via business processes. Also Charles and Walker (2005) indicated that business processes and business process management and systems should be used to make the communication breakthrough between important elements of the supply chain or IFC approaches to gain access into disparate technology systems.

\section{Interfunctional Coordination Barriers and Connected Logistics/Marketing Problems}

For better understanding possible problems and barriers which stood up to marketing and logistics point of view of IFC, authors detected antecedents and consequences of general point of view of IFC. In general, the main roles as antecedents of IFC are played by management and its expertise, experiences and skills. According to the above mentioned three main factors, goals of an organization are determined. Moreover, further factors of IFC, which play important role are information coordination (gaining, analysis, application), organizational structure (systems, procedure), and corporate culture (communication, cooperation, commitment, trust).

The second barrier of IFC as it is known from Cheng et al. (2010) is connected with information coordination. It is important to gain information, analyse it and then use results in the decision process of an enterprise. (Tomášková, 2009) All potential IFC problems and barriers are depicted in the following figure (Figure 2). 
Figure 2: Interfunctional Coordination Connected Barriers

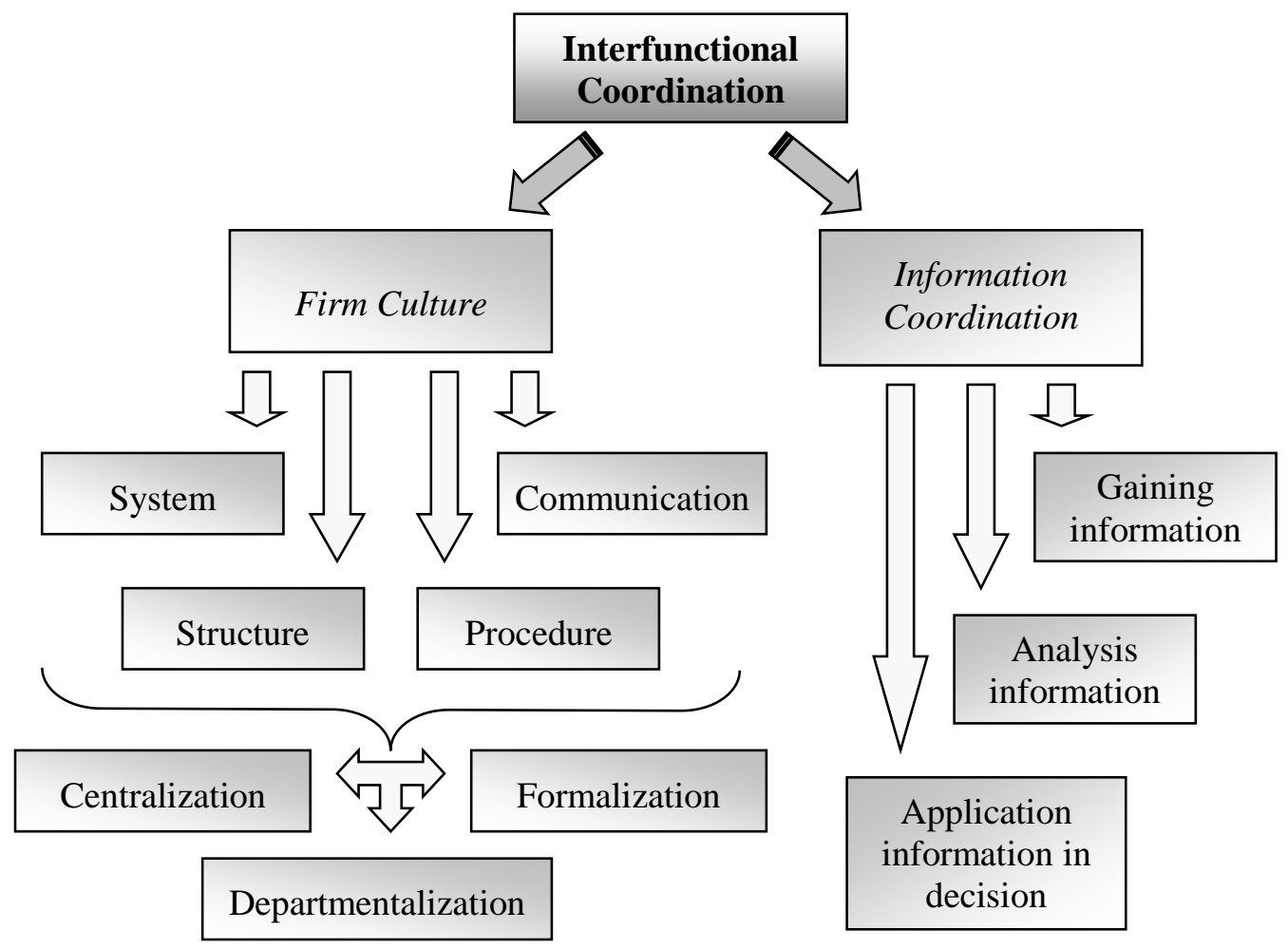

Source: Tomášková (2009)

\section{Discussions and Practical Implications}

As we can see, IFC involves a lot of attitudes. A lot of authors tried to offer the best definition which involves complex of solved tasks, and integrate different conceptions. In general, IFC assumes these activities - to gain information and resources, to share this information and resources within an organization, and finally to choose the best reaction to the information and coordinate response to the competitors action. All these activities have to be promptly coordinated by all departments of company in high quality with low level of resources. If an enterprise has to reach a high level of IFC and cost saving from this level, it is necessary to find out the optimal level of IFC as well as equal balance coordination with other company functions. For a positive effect of IFC it is necessary to ensure perfect communication and support by top management. RQ 1 and 2 were fully confirmed by comprehensive literature survey in chapter 04 Interfunctional Coordination in Marketing and 05 Interfunctional Coordination in Logistics Management. IFC is interesting for logistic as well as for marketing strategy or management. We have divided all gained definitions of IFC into four groups according to the following attributes (see Table 2):

I. Quantitative view - authors defined IFC using categorization which department have to implement this IFC;

II. Qualitative view - authors defined IFC using characteristics of the IFC;

III. View of goals - authors defined IFC using positive influence on business performance of a company;

IV. Marketing view - authors defined IFC using customers' or customers' satisfaction. 
Table 2: A Quantitative and Qualitative Categorisation of Interfunctional Coordination Definition

\begin{tabular}{|c|c|c|c|}
\hline Quantitative View & Qualitative View & View of Goals & Marketing View \\
\hline $\begin{array}{l}\text { Lawrence and Lorch } \\
\text { (1967) }\end{array}$ & Day and Klein (1987) & Hodge et al. (1996) & Porter (1985) \\
\hline $\begin{array}{l}\text { Kohli and Jaworski } \\
\text { (1993) }\end{array}$ & Shapiro (1987) & Woodside (2005) & Narver and Slater (1990) \\
\hline $\begin{array}{l}\text { Kahn and Mentzer } \\
(1996)\end{array}$ & Sinkula (2004) & Cheng, et al. (2010) & $\begin{array}{l}\text { Song and Montoya- } \\
\text { Weiss(2001) }\end{array}$ \\
\hline $\begin{array}{l}\text { Dwyer and Tanner } \\
(1999)\end{array}$ & $\begin{array}{l}\text { Grinstein and Workman } \\
\text { (2004) }\end{array}$ & Hingley, et al. (2011) & $\begin{array}{l}\text { Zhao and Cavusgil } \\
(2006)\end{array}$ \\
\hline Mentzer (2000) & Farzard et al. (2008) & & \\
\hline Mentzer (2001) & $\begin{array}{l}\text { Chopra and Meindl } \\
(2009)\end{array}$ & & \\
\hline $\begin{array}{l}\text { Zahra and George } \\
(2002)\end{array}$ & & & \\
\hline Sahay (2003) & & & \\
\hline Bouranta et al. (2005) & & & \\
\hline $\begin{array}{l}\text { Charles and Walker } \\
(2005)\end{array}$ & & & \\
\hline Gimenez (2006) & & & \\
\hline Tay and Tay (2007) & & & \\
\hline $\begin{array}{l}\text { Chopra and Meindl } \\
\text { (2009) }\end{array}$ & & & \\
\hline $\begin{array}{l}\text { Peng } \\
\text { George(2011) and }\end{array}$ & & & \\
\hline $\begin{array}{l}\text { Ramanathan, } \\
\text { Gunasekaran and } \\
\text { Subramanian (2011) }\end{array}$ & & & \\
\hline
\end{tabular}

Table 2 shows that definitions by authors who are interested in marketing IFC definitions are not the same. They perceive the term of IFC from quantitative, qualitative, goals as well as marketing views. A similar attitude was found by authors, who are interested in IFC from the point of view of logistics. Main authors agree with the quantitative definition of IFC. We fully agree with the IFC conception of Tay and Tay (2007) and Mentzer (2000) who consider IFC as an integration of all functions in an organization from the quantitative point of view. Furthermore, we have to add that it is not sufficient to use only the quantitative approach, but it is also necessary to use the IFC description from the qualitative point of view as well. Probably the most important findings for logistics and marketing IFC understanding was made by Shapiro (1987) and his conceptions. The author defined corporate culture and information coordination as fundamental requirements of ICF. From the managerial approach, we would like to stress Farzard et al. (2008) who noted that adoption of ICF is an important and integral part of structure and strategy.

Present network business environment requires in an enterprise full external (interorganizational coordination) and internal (interfunctional coordination) collaboration which have to be supported by relationships with customers (CRM) and suppliers (SRM). This solution usually combines SCM upstream (logistics) and downstream (marketing) oriented approaches, which leads to creation collaborative approach for different industries (i. e. automotive, aerospace and other manufacturing industries). Complex business network 
environment could be solved by IFC or interdepartmental coordination via suitable micro/macroprocesses analysis, which is able to focus on:

- All processes that focus on the enterprise and its whole environment;

- Interface between the enterprise and its environment, especially customers (CRM) and suppliers (SRM);

- Internal processes which are oriented to the enterprise from the marketing point of view (market orientation) and also Internal Supply Chain Management (ISCM).

One of the tools which authors recommend to use is combination of the external view of surroundings with the integration efforts on the enterprise concepts by $\mathrm{GERA}^{3} / \mathrm{GERAM}^{4} / \mathrm{EEM}^{5}$ or $\mathrm{PERA}^{6} / \mathrm{FADE}^{7} / \mathrm{FADEE}^{8}$.

Finally, authors also answered RQ3 by Tomáškova (2009) findings that IFC main barriers are information coordination, organization coordination, and corporate culture. Every enterprise has to coordinate all of these factors and none of factors have to be ignored. Some enterprises think that it is enough to implement new IS or ICT solution. An enterprise could use various IT technical solutions (e. g. SupplyOn), that is based on virtual hybrid (combination of private and public) cloud solution software as a service solution. Other enterprises think that it is enough to gain information without its detailed analysis, but the truth is that it is necessary to implement IFC in the whole range. Another question is the cost connected dilemma with IFC implementation. If an enterprise wants to reach a high level of IFC and cost saving from this level, it is necessary to find out an optimal level of IFC as well as equal balance coordination with other company functions. A high level of IFC means high cost, but it is necessary to monitor if cost growing brings an increasing level of IFC.

\section{Conclusion}

Currently, successful interfunctional coordination application requires a whole collaborative partner approach, which evolves and adapts all requirements to meet dynamic environment and also partner's needs. According to realised exploratory research of interfunctional coordination, relations between marketing and logistics, which have been made by authors, it is clear that the most important attributes of both disciplines are collaboration, coordination and IT/ICT solution. Description, understanding of all mentioned marketing, and also logistics processes recognition helps to an enterprise to better interface identification between internal boundaries of supply chain management and other disciplines. If enterprise makes the right decision in selection process of enterprise concept, than SCM, purchasing and marketing will fluently help to understand present business network environment.

At the end of the article authors also mentioned construction and implementation of instructional coordination management and organizational structure, which is recommended by present enterprise methodology development. On one hand this article focuses on main areas which are very closely connected with business performance system, but the question is how to measure interfunctional coordination and how to implement interfunctional coordination in different organizations.

\footnotetext{
${ }^{3}$ Generalised enterprise reference architecture

${ }^{4}$ Generalised enterprise reference architecture model

${ }^{5}$ Enterprise engineering methodologies

${ }^{6}$ Purdue Enterprise Reference Architecture

${ }^{7}$ Framework for the architectural development of the enterprise

${ }^{8}$ Framework for the architectural development of the extended enterprise
} 


\section{References}

[1] AUH, S. and B. MENGUC, 2005. Top management team diversity and innovativeness: The moderation role of interfunctional coordination. Industrial Marketing and Management, 34(3), 249-261. ISSN 0019-8501.

[2] ARYEE, G., N, et al., 2008. Supply chain integration using a maturity scale. Journal of Manufacturing Technology Management, 19(5), 559-575. ISSN 1740-038X.

[3] BALLOU, R. H., 2007. The evolution and future of logistics and supply chain management. European Business Review, 19(4), 332-348. ISSN 0955-534X.

[4] BERENTE, N., B. VANDENBOSCH and B. AUBERT, 2009. Information flows and business process integration. Business Process Management Journal, 15(1), 119-141. ISSN 1463-7154.

[5] COLLIS, J. and R. HUSSEY, 2009. Business Research: A practical guide for undergraduate and postgraduate students. $3^{\text {rd }}$ Edition. New York: Palgrave Macmillan. ISBN 978-1403992475.

[6] COSTES, N. F., et al., 2009. Supply chain integration: the role of logistics service providers. International Journal of Productivity and Performance Management, 58(1), 71-91. ISSN 1741-0401.

[7] CHARLES, P. C. and I. WALKER, 2005. Business Process Management Applied: Creating the Value Managed Enterprise. Boca Raton: J. Ross Publishing. ISBN 9781932159332.

[8] CHENG, et al., 2010. The evolutionary process and collaboration in supply chains. Industrial Management \& Data Systems, 110(3), 453-474. ISSN 0263-5577.

[9] CHOPRA, S. and P. MEINDL, 2009. Supply Chain Management: Strategy, Planning, and Operation. $4^{\text {th }}$. Edition. New Jersey: Person Prentice Hall. ISBN 978-0136080404.

[10] CHRISTOPHER, M., 2004. Logistics and Supply Chain Management: Creating Value-Added Networks. $3^{\text {rd }}$. Ed. Harlow: FT Prentice Hall. ISBN 0-273-68176-2.

[11] CHRISTOPHER, M., 1998. Logistics and supply chain management. $2^{\text {nd }}$ edition. London: Financial Times Professional Limited. ISBN 978-0273630494.

[12] DANESE, P. and P. ROMANO, 2004. Improving inter-functional coordination to face high product variety and frequent modification. International Journal of Operations \&Production Management, 24(9), 863-885. ISSN 0144-3577.

[13] DAUGHTERTY, P. J., 2011. Review of logistics and supply chain relationship literature and suggested research agenda. International Journal of Physical Distribution \& Logistics Management, 41(1), 16-31. ISSN 0960-0035.

[14] FAROOQUI, S. U., 2010. Encyclopaedia of Supply Chain Management, vol. III. Global Media. ISBN 9789350439395.

[15] GIMENEZ, C., 2006. Logistics integration processes in the food industry. International Journal of Physical Distribution \& Logistics Management, 36 (3), 231249. ISSN 0960-0035.

[16] GIMENEZ, C. and E. VENTURA, 2005. Logistics-production, logistics-marketing and external integration: their impact on performance. International Journal of Operations \& Production Management, 25(1), 20-38. ISSN 0144-3577. 
[17] HECZKOVÁ, M. a M. STOKLASA, 2011. Customer relationship management theory and principles. Acta academica karviniensia, 11(4), 80-91. ISSN 1212-415X.

[18] HINGLEY, M., 2001. Relationship Management in the Supply Chain. International Journal of Logistics Management, 12(2), 57-71. ISSN 0957-4093.

[19] HINGLEY, M., et al., 2011. Using fourth-party logistics management to improve horizontal collaboration among grocery retailers. Supply Chain Management: An International Journal, 16(5), 316-327. ISSN 1359-8546.

[20] HORVATH, L., 2001. Collaboration: the key to value creation in supply chain. Supply Chain Management: An International Journal, 6(5), 205-207. ISSN 1359-8546.

[21] JÜTTNER, U., et al., 2010. A strategic framework for integrating marketing and supply chain strategies. International Journal of Logistics Management, 21(1), 104126. ISSN 0957-4093.

[22] KAHN, K. B. and J. T. MENTZER, 1996. Logistics and interdepartmental integration. International Journal of Physical Distribution \& Logistics, 26(8), 6-14. ISSN 09600035 .

[23] KAUFMAN, A., et al., 2000. Collaboration and technology linkages: a strategic supplier typology. Strategic Management Journal, 21(6), 649-663. ISSN 1097-0266.

[24] LAMBERT, D. M., M. C. COOPER and J. D. PAGH, 1997. Supply Chain Management: implementation issues and research opportunities. In. International Journal of Logistics Management, p. 1-19. 1997. ISSN 0957-4093.

[25] LUMMUS, R. R., D. W. KRUMWIEDE and R. J. VOKURKA, 2001. The relationship of logistics to supply chain management: developing a common industry definition. Industrial Management \& Data Systems, 101(8), 426-432. ISSN 0263-5577.

[26] MIN, S. and J. T. MENTZER, 2000. The role of marketing in supply chain management. International Journal of Physical Distribution \& Logistics Management, 30(9), 765-787. ISSN 0960-0035.

[27] McCARTHY B. T. M. and J. T. MENTZER, 2011. Integrating supply chain infrastructure and process to create joint value. International Journal of Physical Distribution \& Logistics Management, 41(2), 135-161. ISSN 0960-0035.

[28] McNAUGHTON, R. B., et al., 1999. Intranet adoption and inter-functional coordination. Journal of Marketing Management, 15(5), 387-403. ISSN 0267-257X.

[29] MENTZER, J. T., 2000. Supply Chain Management. $1^{\text {st }}$ ed. Thousand Oaks: Sage Publications. ISBN 0-7619-2111-7.

[30] O'DWYER, M. and A. LEDWITH, 2009. Determinants of new product performance in small firms. International Journal of Entrepreneurial Behaviour \& Research, 15 (2), 124-136. ISSN 1355-2554.

[31] PATNAYAKUNI, et al., 2006. Relational antecedents of information flow integration for supply chain coordination. Journal of Management Information Systems, 23(1), 1349. ISSN 0742-1222.

[32] PIRITHIVIRAJ, J. C. D. and K. KAJENDRA, 2010. Relationship between Market Orientation and Corporate Social Responsibility with special reference to Sri Lanka Financial Sector. Journal of Emerging Trends in Economics and Management Sciences, 1(2), 107-113. ISSN 2141-7024. 
[33] POIRIER, CH. C., et al., 2003. Networked supply chain: Applying breakthrough business process management technology to meet relentless customer demands. Boca Raton: J. Ross Publishing. ISBN 9781932159080.

[34] QIANG, L., et al., 2008. Inter-functional coordination in product realization: A framework for future research. In. Management of Innovation and Technology 2008, p. 402-407. ISBN 978-1-4244-2330-9.

[35] RAMANATHAN, U., A. GUNASEKARAN, and N. SUBRAMANIAN, 2011. Supply chain collaboration performance metrics: a conceptual framework. Benchmarking: An International Journal, 18(6), 856-872. ISBN 1463-5771.

[36] RAFIQ, M. and P. K. AHMED, 1993. The scope of internal marketing: defining the boundary between marketing and human resource management. Journal of Marketing Management, 9(3), 219-232. ISSN 1472-1376.

[37] SAHAY, B. S., 2003. Supply chain collaboration: the key to value creation. Work study, 52(2), 76-83. ISSN 0043-8022.

[38] SCOTT, C., et al., 2011. Guide to Supply Chain Management. $1^{\text {st }}$ edition. New York: Springer. ISBN 978-3-642-17675-3.

[39] SIMATUPANG, T. M., I. V. SANDROTO and S. B. H. LUBIS, 2004. Supply chain coordination in a fashion firm. Supply Chain Management: An International Journal, 9(3), 256-268. ISSN 1359-8546.

[40] SIMATUPANG, T. M. and R. SRIDHARAN, 2003. The Collaborative Supply Chain. The International Journal of Logistics Management, 13(1), 15-30. ISSN 0957-4093.

[41] SIMATUPANG, T. M. and R. SRIDHARAN, 2005. An integrative Framework for supply chain collaboration. The International Journal of Logistics Management, 16(2), 257-274. ISSN 0957-4093.

[42] SIMATUPANG, T. M. and R. SRIDHARAN, 2008. Design for supply chain collaboration. Business Process Management Journal, 14(3), 401-418. ISSN 14637154.

[43] SOUDER, W. E, et al., 1977. An exploratory study of the coordinating mechanisms between $R \& D$ and marketing as an influence on the innovation process. Final Report to the National Science Foundation., NTIS number PB 279-366.

[44] SWINK, M., et al., 2007. Managing beyond the factory walls: effects of four types of strategic integration on manufacturing plant performance. Journal of Operation Management, 25(1), 148-164. ISSN 0272-6963.

[45] TAY, J. Y. W. and L. TAY, 2007. Market orientation and the property development business in Singapore. International Journal of Strategic Property Management, 2007, 11(1), 1-16. ISSN 1648-9179.

[46] TJOSVOLD, D., 1988. Cooperative and competitive interdependence: collaboration between departments to serve customers. Group and Organization Studies, 13(3), 274289. ISSN 1741-3044.

[47] TOMÁŠKOVÁ, E., 2005. Měření tržní orientace a její vliv na podnikový výkon, Brno: Vutium. ISBN 8021430273.

[48] TOMÁŠKOVÁ, E., 2009. Internal Barriers of Market Orientation Application. Economic and Management, 14(14), 535-541. ISSN 1822-6515. 
[49] ZAILANI, S., et al., 2005. Supply chain integration and performance: US versus East Asian companies. Supply Chain Management: An International Journal, 10(5), 379393. ISSN 1359-8546. 